\title{
The Health Sciences and Technology Academy (HSTA): Providing 26 Years of Academic and Social Support to Appalachian Youth in West Virginia
}

Ann Chester, $\mathrm{PhD}^{1 *}$, Sherron McKendall, $\mathrm{PhD}^{1 *}$, Alan McKendall, $\mathrm{PhD}^{2}$, Michael Mann, $\mathrm{PhD}^{3}$, Alfgeir Kristjansson $\mathrm{PhD}^{4}$, Robert Branch, MD, FRCP5 , Bethany Hornbeck ${ }^{1}$, Catherine Morton, EdD¹, Summer Kuhn, MA ${ }^{1}$, Feon Smith Branch, $\mathrm{PhD}^{6}$, and Charlene Barnes-Rowland, $\mathrm{EdD}^{7}$

${ }^{1}$ Health Sciences and Technology Academy, ${ }^{2}$ ndustrial and Management Systems Engineering, and ${ }^{4}$ School of Public Health, West Virginia University, Morgantown, WV; ${ }^{3}$ Department of Community and Environmental Health, Boise State University, Boise, ID; ${ }^{5}$ Department of Medicine (Emeritus), University of Pittsburgh,

Pittsburgh, PA; ${ }^{6}$ College of Education and Professional Development, Marshall University, Huntington, WV; and ${ }^{7}$ Department of Education, Bethany College, Bethany, WV; * Co-primary authors

Keywords: Science Mentoring, High School, Out-of-School-Time Programs, Underrepresented, Minority, First Generation, Financially Disadvantaged, Fun, Friends, Funds, Recreation, Relationships, Reward, Research, Relevance, Rigor, Repetition, Community-Owned, Community-Run, Health Literacy, STEM Workforce, STEM Major, STEM Degree, Summer Camp, After-School Club, Teacher-Led, Teacher Professional Development

Publication Date: October 21, 2020

DOI: https://doi.org/10.15695/jstem/v3i3.04

\begin{abstract}
The Health Sciences and Technology Academy's, (HSTA) goals are to increase college attendance of African American, financially disadvantaged, first generation college and rural Appalachian youth and increase health-care providers and STEM professionals in underserved communities. Students enter in the 9th grade and remain in HSTA four years. They engage in a rigorous academic program within the nurturing environment of small after-school clubs punctuated by yearly summer camps on multiple college campuses. A distinctive piece of HSTA is its students' development of research projects under the mentorship of teachers and researchers that examine and address health issues faced by their communities. The projects help HSTA students to understand the health dynamics in their local community, transforming them into community advocates who address health and social issues at home as they prepare to move on to college and beyond. Substantial in-state tuition waivers inspire $99 \%$ of the 3,021 HSTA graduates to attend college versus $56 \%$ of WV high school graduates. Approximately $85 \%$ of matriculating HSTA students graduate with a four-year degree or higher versus less than $50 \%$ of all college entrants. To date, $57 \%$ of HSTA students go into health and other STEM majors, much higher than the state and national figures.
\end{abstract}

\section{INTRODUCTION}

The Health Sciences and Technology Academy, known as HSTA, is an Out of School Time (OST) academic enrichment and mentoring program in the state of West Virginia. This program helps underrepresented high school students enter and succeed in STEM-based undergraduate and graduate degree programs. HSTA marshals the efforts of hundreds of mentors, teachers, community members, higher education faculty and staff, and the HSTA participants themselves through an infrastructure that supports students facing social and financial challenges. HSTA participants receive the help they need to obtain a high school diploma and further their education.

Since its inception in 1994, the program has grown from nine teachers serving 44 students in two West Virginia coun- ties to a network of 80 teachers serving approximately 800 students annually across the state. HSTA participants are 9th through 12th grade students who live in rural communities. Over $60 \%$ are first in their families to attend college. About half are financially disadvantaged, and one-third are African American (Figure 1). As of 2019, 87\% of HSTA graduates have obtained a college education, and $27 \%$ have earned advanced degrees.

Implemented through West Virginia University, HSTA's main goals are to increase college attendance and graduation rates of African American, financially disadvantaged, first generation college and rural Appalachian youth, improve STEM education in public schools, empower communities through youth leadership, and increase the number of health- 


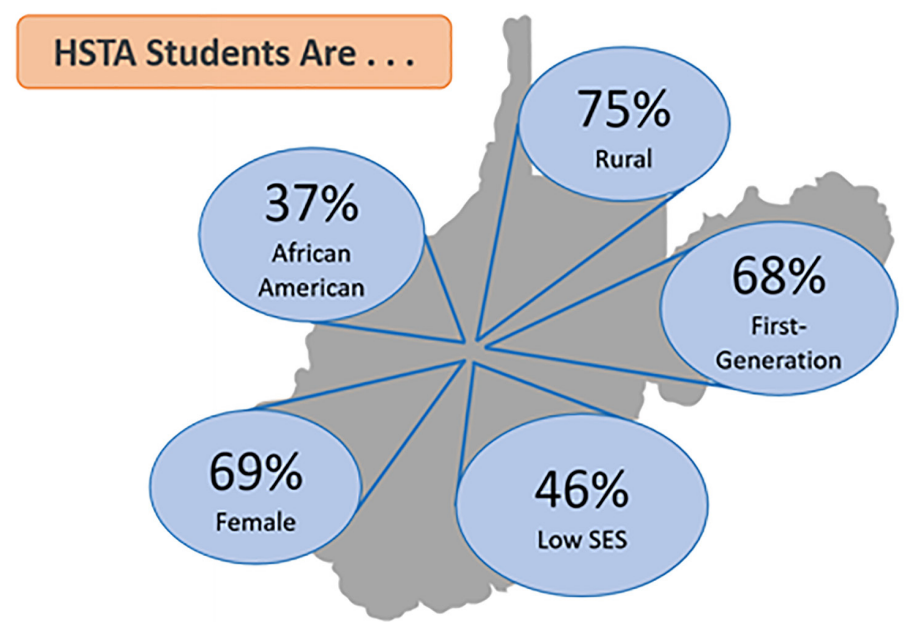

Figure 1. Demographics of HSTA.

care providers and STEM educators in underserved communities. To realize these goals, HSTA created a mentorship structure that guides and supports student success and addresses individual educational and social needs.

The program puts rigorous academic expectations into place that connect learning to students' personal experiences. It rewards participants with generous incentives that recognize their accomplishments. Most noteworthy is it offers, through the support of the West Virginia Legislature, and state colleges and universities, substantial tuition waivers to successful participants who go on to attend an in-state institution for an undergraduate degree. This waiver legislation also allows a HSTA student to pursue a STEM-based masters and terminal degree upon completing the undergraduate degree.

Key Program Elements. The HSTA program implements four key program elements, which include the following:

Out of School Time Club. All students attend the out of school time program, a proven best practice for social and academic support throughout their four years in the HSTA program (Chittum et al., 2017; Krishnamurthi et al., 2014; Rye and Chester, 1999; Sahin, 2013). The clubs are a multigrade level experience in which there is a mixture of 9th through 12th graders. Teachers mentor students in these local clubs after school with a student-teacher ratio of 10:1, which allows teachers to provide personal attention and individualized academic support (Rye and Chester, 1999). Students also receive guidance from scientists, peer mentors, HSTA staff and community leaders, while forming intimate cohorts that work together to tackle the rigors of the program. During club meetings, students engage in STEM and health sciences activities, icebreakers, team-building exercises, and other activities to build camaraderie and social skills. They receive visits from HSTA alumni and other guests who teach content, conduct hands-on activities, provide encourage- ment, and model success. Most importantly, they engage in year-long community based participatory research projects designed to positively impact their communities (Bardwell et al., 2009; Siciliano et al., 2018; Tompkins et al., 2005; Zizzi et al., 2009).

Long-Term Research Project. Student led community-based research projects are among the most distinctive elements of the HSTA program, as they are also a proven strategy for teaching college readiness skills (Donham, 2014; Lescak et al., 2019; Noguera et al., 2015; Rutledge, 2005; Swan et al., 2018). Over their four years with HSTA, students design and lead four research projects designed to bring positive impact to their communities. HSTA community-based projects examine and address health issues relevant to the participants and their communities. These projects form the core of the HSTA experience and framework and are how HSTA helps students learn to learn, which is an important skill related to college and STEM success. When their projects are completed, students present their research findings to their peers, families, teachers, community members, and a panel of judges during an annual capstone symposium held at the end of the academic year. All students must earn a passing score on their presentation to continue in the program, with outstanding students receiving additional recognition.

Summer Camps. Each year, HSTA students also have the opportunity to attend free camps on multiple university campuses throughout West Virginia (Rye and Chester, 1999). The summer camps are peer/grade level one- to three-week experiences that also provide a proven best practice to improve STEM interest (Baran et al., 2019; Beer et al., 2008; Kitchen et al., 2018; Moor-Schroeder et al., 2014). Rising first-year students (freshmen) attend a high-level science camp introducing them to hands-on laboratory work infused with technology-rich problem-solving games. Sophomores

Table 1. Analysis of Variance Effect Tests for HSTA vs. Comparison Groups, 2016-2018 (F-value and p-value).

\begin{tabular}{|c|c|c|c|}
\hline & F-value & $p$-value & References \\
\hline Social Support & 4.83 & $.008^{*}$ & Zimet et al., 1988 \\
\hline Academic Intentions & 3.78 & $.023 *$ & HSTA developed scale \\
\hline Problem-Focused Coping & 3.39 & $.034 *$ & $\begin{array}{l}\text { Carver, } 1997 \\
\text { Wilson et al., } 2005\end{array}$ \\
\hline $\begin{array}{l}\text { Community Engagement } \\
\text { Scale A }\end{array}$ & 2.83 & .059 & $\begin{array}{l}\text { Kristjansson and } \\
\text { Mann, } 2018\end{array}$ \\
\hline $\begin{array}{l}\text { Engaging Differences } \\
\text { Main }\end{array}$ & 1.75 & .173 & Hurtado et al., n.d. \\
\hline $\begin{array}{l}\text { Engaging Differences } \\
\text { Outcome Behavior }\end{array}$ & 1.45 & .233 & Hurtado, S. et al., n.d. \\
\hline Pro-Academic Identity & 0.51 & .603 & Midgley et al., 2000 \\
\hline $\begin{array}{l}\text { Community Engagement } \\
\text { Scale B }\end{array}$ & 0.43 & .650 & $\begin{array}{l}\text { Kristjansson and } \\
\text { Mann, } 2018\end{array}$ \\
\hline
\end{tabular}


attend a one-week camp that immerses them in forensic science through mock crime scenarios and investigative techniques. Juniors can attend a one-week camp devoted to understanding and reducing the incidence of metabolic syndrome, including sessions focused on anatomy. Through small group sessions, students collaborate with laboratory bench or social scientists in pathology, anatomy or medicine faculty, allowing for deep and rich learning to take place. Seniors are eligible to participate in a three-week statistics camp in which they can earn three college credits. Regardless of grade level (i.e., Freshmen through Senior), HSTA camp participants are immersed in research, classroom or recreational activities from approximately 7:00 am to 10:00 pm during their one or three week stay on campus.

All students are required to attend a minimum of two camps during their four years in the HSTA program. These camps provide them with the opportunity to forge meaningful friendships and to experience a fun and interactive learning environment as well as spend hours with near-peer mentors, many of whom are HSTA alumni themselves (Patel et al., 2015). Participants become familiar with the college environment and observe authentic examples of people who have successfully navigated higher education and chosen careers in science.

Mentoring and Modeling. In each of the three key program elements described above, participants are exposed to models and connected to mentors, improving retention (Castleman and Page, 2015; Chan et al., 2019; McKendall et al., 2014; Patel et al., 2015; Smith-Branch et al., 2018; Tierney and Garcia, 2014; Wrensford et al., 2019). The HSTA family is a broad and deep support network that includes teachers, administrative staff, near-peer college students, community members, university faculty and staff, students' families, and the HSTA students themselves. Within this vibrant community, HSTA students interact with exemplars and participate in mentoring on many levels. Participants meet a wide range of guest speakers who model success in scientific careers, spend weeks working with university scientists, near-peer mentors, and camp faculty, and receive years of sustained individual attention from out of school time club teachers and other HSTA staff.

Key Strategies. HSTA integrates seven key strategies into each of the key program elements listed above (Chester et al., 2018). These key strategies help participants develop beyond the classic "Three Rs: Reading, Writing, and Arithmetic." These key strategies are referred to as the "Seven Rs" and include: Reward, Relationships, Recreation, Research, Relevance, Rigor, and Repetition. The first three Rs (Reward, Relationship, and Recreation) create a context that fuels and sustains student motivation to engage successfully in the next four Rs (Research, Relevance, Rigor, and Repe- tition). Together, the Seven Rs infuse the program with the energy and motivation that HSTA students carry through their lifetimes.

\section{Key Strategies 1-3: The Foundational Rs.}

Reward. HSTA's primary reward is to offer participants who complete the program a tuition-free undergraduate degree in any discipline and a master's and/or doctoral-level degree in nearly any STEM major at West Virginia state-funded colleges/universities. Upon successfully completing HSTA and receipt of the tuition waiver, the HSTA student must continue to meet the academic requirements of their chosen college and selected degree program. This incentive provides the financial stability for hundreds of youth who thought the cost for college to be an insurmountable barrier. It functions as an enticement for students to enter and persist through the rigors of the program, reaping the many benefits beyond the waiver during their four years with HSTA (Martinez and Klopott, 2005; McKendall et al., 2014; Mercer, 1992; Tierney and Hagedorn, 2002). Participants have reported that the tuition waivers, social relationships/friends, enjoyment/fun, and the program's relevance to their interest and attaining their goals were key components to enrolling in and remaining in HSTA. HSTA students also reported that exposure to the diversity of individuals, encountering challenges and overcoming those challenges as well as gaining confidence and assertiveness were key benefits of the program (Kristjansson and Mann, 2018).

Relationships. HSTA works to provide participants with a sense of belonging, one of the greatest needs of an adolescent (Bialeschki, 2007; Dewey, 1938; Pendergast et al., 2018; Strayhorn, 2019; Zeldin et al., 2018). HSTA purposefully supports students in a rich, family-like atmosphere. All key program elements utilize low teacher-to-student ratios of no more than 1:10. A teacher leads every club with assistance from a field site coordinator and a community research associate. Together, they help with club activities and work with the kids on their annual projects (Stevanovic, 2017) for an adult-to-student ratio of almost 1:3. The field site coordinator helps with snacks, materials and supplies and often assists the teacher in club discipline. The community research associate (CRA) is instrumental in designing and assisting teachers with disseminating the HSTA curriculum. These CRAs also assist teachers with helping students to conduct the research process and are important to maintaining the academic/research rigor of the program. At summer camps, students encounter relationships with HSTA faculty and staff, university faculty and staff, and college-aged camp counselors, many of whom are HSTA alumni themselves. These adults teach, coach, oversee, and support the students through their camp experience, again with teacher-to-students ratios that never exceed 1:10 and that are often lower. 
In addition to the HSTA adults' mentorship, participants' relationships with each other create intimate student cohorts within its after-school club and summer camp settings. Faced with a common challenge - the annual research project-HSTA kids form a bond that functions like the bond of a sports team or theater troupe. They help one another, they cheer one another on, and they support one another through good times and bad benefitting from the camaraderie with other students with similar interests and goals.

Recreation. Experience has shown if it's not fun, the students won't stay or will be less engaged learners (Fix et al., 2019; Wilson et al., 2011). This premise has been shown in HSTA research through a 2014-18 study conducted via a grant from the Annie E. Casey Foundation. The most significant reason for HSTA students persisting in the program appeared to be fun (Kristjansson and Mann, 2018). Naturally interwoven into the program's fabric, fun happens via field trips during the school year, evenings out during summer camps and activities designed to balance rigorous work with play (Hutson, Cooper and Talbot, 2011). The purpose is to strengthen their bonds of friendship, their sense of community, and the family-like atmosphere that they report is so important to them persisting in the program.

\section{Key Strategies 4-7: The Skills Building Rs.}

Research. Actively involving students in science by supporting their efforts to conduct original research comprises the core activity of the HSTA program. Conducting their own research helps students learn to problem-solve, communicate, understand scientific principles, use logic and statistics, engage in data-driven decision-making, and report their findings. Research provides the opportunity for students to do all of this while pursuing answers to questions that matter to them and their communities in a practical, hands-on manner that promises to make a real difference (NSSE, 2007; Podolak and Walters, 2016; Rivers et al., 2020; Swan et al., 2018; Tai et al., 2006).

Relevance. While research provides the foundation for the HSTA structure, relevance provides the foundation for the participants' research. During the course of an academic school year, participants are required to conduct and publicly present before a panel of judges a project that meets the requirements of a rigorous research rubric. To keep participants motivated, HSTA staff provides opportunities for students to identify problems in their community to solve, which makes for a more meaningful and relevant research experience. HSTA participants receive training in how to examine, analyze, and dissect problems for greater understanding, and to test interventions and solutions using research. The process is difficult and demanding, but offers an opportunity to make a difference in their community, increas- es relationships between community and higher education while connecting them to their community/state so that they become health advocates for themselves, peers, family and community (Bialeschki, 2007; Dewey 1938; Kitchen et al., 2018; Rendón, 2000; Rendón, 2006; Woodlief et al., 2003).

Rigor. As students matriculate through the program, project rigor must increase, with expectations of leading younger students and/or working independently. Younger participants may work in teams with participants their age, or they may collaborate with a HSTA "upper class veteran" who is proficient in doing the projects and wants to share their insight and knowledge with a new HSTA student. Requiring rigor in participants' projects is a key component in building confidence, preparing them to become successful researchers, which is a known important attribute in post-secondary study (Edmunds et al., 2017; Martinez and Klopott, 2005).

Repetition. Students enter HSTA at the beginning of the 9th grade to allow adequate time to develop academic and life skills (Kang, 2016; Reynolds and Glaser, 1964). In year one, a student is immersed into the HSTA environment and begins to learn about the various facets of the program (e.g., conducting research, building relationships). By year's end, they begin to comprehend the program's inter-workings. In year two, understanding deepens, and participants begin to connect what they are doing with what they are learning. In year three, they are more ready to work independently, applying skills to increase the rigor of their projects. They can analyze their own work to determine what they can do next time for improvements. By year four, they are closer to mastery, and many veteran HSTA participants are ready to teach others.

For these reasons, HSTA is not a one-year program, or a two-year program, but a four-year effort to ensure scaffolding of critical academic skills so that by the time they reach college, they are ready to take on the challenge and excel. Such efforts have resulted in an unprecedented rate of $85 \%$ of HSTA graduates attaining a 4-year degree or higher (Health Sciences and Technology Academy, 2019; McKendall et al., 2014). These college persistence outcomes are realized without any additional formal HSTA academic or social assistance once they graduate from high school. Currently, $76 \%(\mathrm{~N}=1129)$ of HSTA graduates enrolled in college attend WVU and other West Virginia Institutions of higher learning. These institutions offer programs designed to help underrepresented and at-risk students stay on track and succeed. The RISE WVU program is one such example in which students of color and other underrepresented students have opportunities to build academic communities or the Office of Student Success at Fairmont State University, which offers formal supports to assist with the transition from high school to college, persistence in college, and ultimately 
success through graduation (West Virginia University, n.d.; Fairmont State University, n.d.; Marshall University, 2017). An informal support network offered through HSTA is the HSTA Alumni Association. Formally established in 2017, this network provides an opportunity for HSTA graduates to connect with and support each other. (Health Sciences and Technology Academy, n.d.).

\section{EVALUATION}

HSTA's mission is to support and ensure the success of promising underrepresented students who are pursuing careers in a health sciences/STEM field. During the 25 years for which the program has tracked participant outcomes, results have been consistently positive for the students who completed the full four year program (Figure 2; College Board Advocacy and Policy Center 2012; Heuer et al. 2016; IES, 2019; U.S. Bureau of Labor Statistics, 2017; U.S. Census Bureau, 2018; WVHEPC, 2016). Of the five most recent incoming 9th grade cohorts from 2010 through 2015, 64\% of the 1,292 persisted four years to successfully graduate from the program. This means they voluntarily, stayed in an optional program for four straight years despite the demands and requirements beyond their school work and afterschool activities.

Between 1994 and $2019(\mathrm{~N}=1369)$ :

- $99 \%$ of HSTA program graduates matriculated to college compared with general-population rates of $69.7 \%$ nationally and $54.7 \%$ in WV (U.S. Bureau of Labor Statistics, 2017; WVHEPC, 2016)

- $85 \%$ of HSTA program graduates obtained a fouryear degree or higher versus $48.2 \%$ of the general population of entering freshman in WV and 57.7\% (College Board Advocacy and Policy Center, 2012) in the U.S. Additionally, only $19.2 \%$ of entering freshmen from underrepresented minority populations and $22.4 \%$ of low-income entering freshmen in WV completed their degrees. (Heuer et al., 2016; WVHEPC, 2016).

- $57 \%$ of HSTA program graduates pursued health/ STEM degrees compared to less than $30 \%$ nationally and in WV (IES, 2019; U.S. Census Bureau, 2018).

- $85 \%$ of HSTA program graduates remained in WV after graduation, contributing professionally to the communities that invested in them (Chester and Dooley, 2011; Hutton, 2014).

One can argue that these students were exceptional to begin with, and that they would have succeeded without HSTA. However, only $32 \%$ of the students have anyone in their family who went to college before them. The familial cycle of low educational attainment is being broken.
HSTA Students Achieve High Rates of Matriculation, Graduation, and Pursuit of STEM Careers

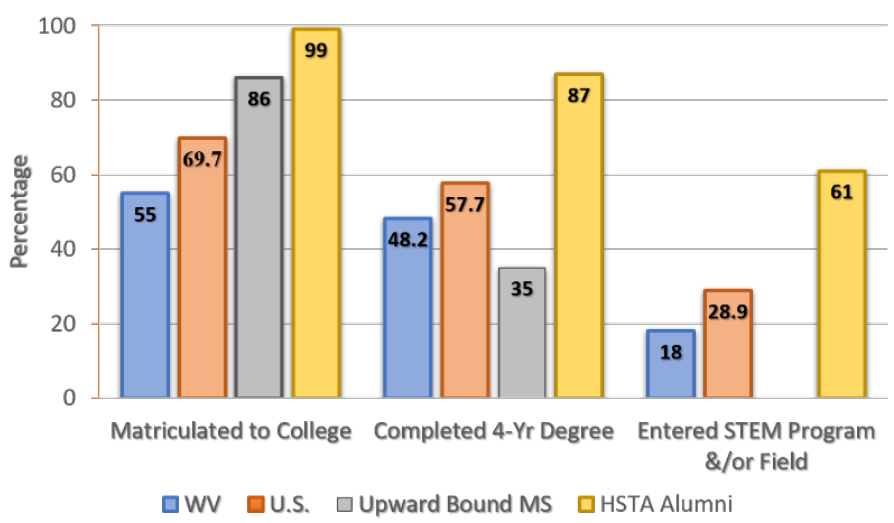

Source: U.S. Department of Education, National Center for Education Statistics, Higher Education General Information Survey (HEGIS).

Figure 2. Comparison of Educational Attainment of HSTA alumni compared with the general population of WV, US, and Upward Bound.

HSTA programming has been consistently evaluated since inception. The first publication that featured the HSTA program was available in Academic Medicine in 1999 (Rye and Chester, 1999). This article described positive outcomes associated with the program. Since then, numerous studies have highlighted the program's success over two decades, including HSTA students exhibiting higher performance in college (McKendall et al., 2019), greater persistence in college (McKendall et al., 2000), greater persistence in STEM majors (McKendall et al., 2000), higher standardized test scores in high school (Smith-Branch et al., 2018), increasing recruitment of underserved students into the STEM workforce (Griffith, 2019; McKendall et al., 2014), and increasing health literacy and healthy behaviors among participants and their families (Chester et al., 2018).

HSTA's organizational structure is community leadership, local out of school time clubs led by local teachers, implementation of personally relevant research requirements led by CRAs (Rye and Chester, 1999), multiple summer camps, and a four-year requirement for completion. This infrastructure is effective in four ways: 1) increasing educational attainment of participants (McKendall et al., 2000); 2) increasing recruitment of underserved students into the STEM workforce (Griffith, 2019; McKendall et al., 2014); 3 ) increasing health literacy and healthy behaviors among participants and their families (Chester et al., 2018); and 4) increasing scientists' access to under-served populations through the ability of students to partner in substantial ways with active research scientists (Siciliano et al., 2018).

These findings have emerged over two and a half decades. It takes time to see results. Usually, this puts limitations on program refinement in the short term. The good news is that HSTA students have proven remarkably accurate in determining their own directions in the 9th grade. In 
Degree Distribution of HSTA Gradutes Earning a Bachelor's Degree or Higher, 1994 - 2019

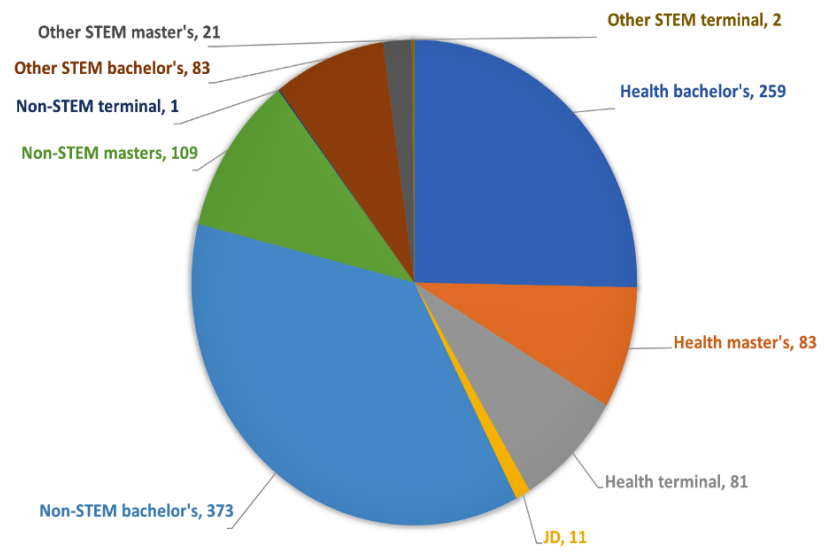

Figure 3. Degree of distribution of HSTA graduates earning a Bachelor's degree or higher, 1994-2019.

a 2014 study comparing HSTA graduates' (1997-2010) educational outcomes compared to their educational aspirations, it was found that as 9th through 12th graders, HSTA participants underestimated their educational aspirations while in the program (Figure 3). Ninety-three percent stated that they would definitely attend college, whereas, $96 \%$ of the graduates in these cohorts attended college (McKendall et al., 2014). This was also the case for HSTA African American 9th through 12 th graders with $95 \%$ indicating definite college attendance; whereas, $97 \%$ of these graduates most definitely attended college. Outcomes for intentions to pursue a health professions degree were nearly as accurate. The study also found that as 9th through 12th graders, $66 \%$ of these HSTA students highly predicted they would pursue a health professions major with $59 \%$ doing so. Sixty percent of the African American students in this study estimated they would pursue a health professional degree with $52 \%$ doing so. Overall, HSTA graduates have and continue to successfully pursue post-secondary education. They attend college, stay in college to graduate, and major in science, technology, engineering, and math (STEM) subjects at higher rates than both the general West Virginia and the national population (McKendall et al., 2014). Given this outcome, the evaluation team is validating survey instruments to determine shortterm indicators of these long-term outcomes.

Through a grant from the Annie E. Casey Foundation, in 2013 and 2014, HSTA conducted an intensive evaluation of its program (Kristjansson and Mann, 2018). The project began with a series of focus groups and interviews of HSTA community leaders and key personnel and the development of a detailed program conceptual model. Next, a quasi-experimental, longitudinal, mixed-methods study was conducted that compared HSTA students to a comparison group on a wide-range of variables theorized to contribute to longterm student success. Through the REDCap database, a total of 1,819 current HSTA students and 3,165 non-HSTA stu- dents completed a battery of 8 validated measures annually between 2016 through 2018 (Harris, 2019), while 18 HSTA students participated in qualitative interviews. Additionally, 392 HSTA alumni completed a similar survey used for an exploratory, retrospective analyses related to HSTA outcomes.

Quantitatively, longitudinal survey data indicated that then current HSTA students reported higher levels of pro-academic identity, social support, problem focused coping skills, and academic intentions than a purposefully sampled comparison group (Carver, 1997; HSTA developed scale, 2014; Midgley et al., 2000; Wilson et al., 2005; Zimet et al., 1988). Of special importance, the HSTA program appeared to support students maintaining initially high levels of each of these variables, while the comparison group experienced declines in the absence of program support.

Qualitative data supported quantitative findings suggesting the importance of tuition waivers (rewards), social relationships and friendships (relationships), program enjoyment and fun (recreation), and program relevance to their personal interests and life goals. These findings were key to participants initiating and remaining in the HSTA program. Qualitative themes also emerged regarding the high value HSTA students placed on exposure to students of different races and cultures, experiencing challenge and overcoming challenge (rigor) to become more confident and assertive while in the program.

Finally, an analysis of HSTA alumni data suggested the variables in the Conceptual Model made an important contribution in adult ratings with reference to quality of life; capacity to engage differences in race, gender, and culture; and behaviors associated with community engagement. Especially important, the HSTA program's contributions to maintaining higher levels of pro-academic identity, social support, and problem-focused coping appeared to help explain a significant portion of alumni's higher quality of life ratings.

Qualitative comments from student and teacher participants across the years represent the impact of the social and programmatic elements of HSTA (Health Sciences and Technology Academy On-line Surveys, 2015-2020; McKendall et al., 2014). Examples of student and teacher participants' comments are below:

I liked how we got to dissect the sheep hearts, kidneys, eyes, and how we could dissect the cow eyes. We learned how to cut in the right places and how to focus on the chambers of the heart and the lens of the eye because those were the two features that were closer to humans.

[I]t was really impacting and inspiring while at the same time having people providing comfort and support. 
I loved learning about what all goes into solving a case. It showed me things I didn't know step-by-step.

During my biomedical HSTA camp, I learned a lot from my group project, including health disparities because before I came here, I didn't know what a disparity was, so I'm glad I know now.

I got an inside look on what attending MU (Marshall University) would be like and I think that you just might see me. School was never an option growing up, being in foster homes didn't give me any hope that one day I would turn out to be this young lady I am now. I thought that I wouldn't make (it) past the age of ten, but I did it was a challenge but I did it, I didn't turn out like a druggie I turned out to be a smart, kind, young lady. MU made me see that in me and I hope other people can climb out of their hole that people have put them in or that they dug for themselves and change their lives or the ones around them. It might be difficult at first but there's always a light at the end of the tunnel and if they run fast of enough then they can make it. I'm going to spread the word about MU to my friends and tell them how nice it really is, and how there is so much nature ready to soothe you when your upset or even when your happy. I really liked my stay at Marshall University.

I liked the hands on experience of the cadaver and getting an idea of what types of things I will possibly do in my college courses, if I decide to pursue a career in health care or even science. I also enjoyed the mentor panel so I can get a more realistic perspective on college life and study specifically at WVU. I liked goal setting because it gave me a fresh sense of inspiration to go at my goals head on without hesitation

HSTA is a safe place for many of my students. They know that they get to come see me each week (or whenever they need) and I will make sure they have what they need. It becomes like a family for them that they can count on and depend on for support. They know that one time a week they are getting that extra meal before they go home; they know that we can help them complete those tough homework assignments; they know that we can help guide them in their hard life decisions about after high school or maybe even things about high school; and they know that when they need a shoulder to cry on, we're there for them. It is an amazing program that not just benefits students, but also the teachers.
The major strengths of the HSTA program are the bonds you form with other HSTA students, the leadership and speaking skills you obtain through completing HSTA objectives, the required hours of community service that inspires students to willingly help others, and the summer camps where students learn, have fun, and grow up together at the same time.

\section{FUNDING}

Deeply ingrained into the lives of West Virginians are the health and educational disparities that have historically and currently plague the state (Ziegler, n.d.). The HSTA model supports students with potential, from the communities that suffer the most, as they work to become successful in college and as health care professionals in their home communities. HSTA began in 1994 with an initial budget of $\$ 175,000$ for five years from Howard Hughes Medical Institute (HHMI). The hope was, if the HSTA model worked in the most rural and urban environments in WV, it would work in all of WV to recruit health professionals to work in areas most in need of access to quality health care. Within the first year, the excitement grew from the enthusiastic students and teachers to provide support to go for additional funding. For over two decades, HSTA has been able to assist so many students to reach their potential through community support and legislative buy-in. According to Dr. Ann Chester, HSTA founder, "(what) we are is a community/campus partnership with multiple campuses and community leadership from around the state. Those community members started making a difference. They're the ones who knew which students needed HSTA the most. They're the ones who were able to get the legislature to pass the tuition waiver back in 1997" (Elza, 2019). HHMI would go on to be one of the largest funders over the next decade. In 1995, the W. K. Kellogg Foundation funded HSTA one time for five years to expand to ten counties for nearly $\$ 2 \mathrm{M}$. The directive from Kellogg was that HSTA governance needed to be over $50 \%$ volunteer community leaders. A grassroots infrastructure was built with local governing boards in each region and a state-wide joint governing board to oversee the program. WVU was to act as the fiscal backbone but could not own the program. Kellogg is credited with much of HSTA's success, as their contributions related to ensuring community leadership and ownership has been critical to the program's sustainability over time. For example, in 1997 this community leadership structure engaged leaders from all across the state who were able to work together to ensure the passage of legislation to provide a tuition waiver for HSTA completers.

In 1997, the National Institutes of Health Science Education Partnership Award (NIH SEPA) funded HSTA in what would be the beginning of 23 years of support and expansion 
into multiple counties (Figure 4). The Coca Cola Foundation funded $\$ 300,000$ for three years to expand into two more counties. In 1998, the public colleges and universities in WV collaborated to provide substantial tuition waivers through any degree at the undergraduate level and through STEM terminal degrees. The Claude W. Benedum Foundation would join in funding $\$ 300,000$, and the West Virginia Legislature would begin supporting HSTA to become the largest single supporter 23 years later (Table 2). HSTA has been stable since 2007 when SEPA funds brought the total number of HSTA counties to 26 out of 55 total in WV (Figure 4). While many of the funders have changed over the years, some have remained constant: the West Virginia Legislature, the National Institutes of Health, Howard Hughes Medical Institute, and the Claude W. Benedum Foundation (Table 2).

Partnerships that have played major roles in sustainability are as follows:

Community Support. From the beginning, HSTA communities understood the importance of this program in dismantling the barriers to their children's academic and social success. Through grassroots initiatives, HSTA survived and flourished into the program it is today. As such, HSTA's success is due to the community it serves, for without the community, there is no HSTA.

Community Leadership Support. The HSTA community leaders follow suit, keeping their legislators informed of the results of the HSTA funds, showing the success figures with faces of alumni who are now working in the local regions because of HSTA. This local leadership is relentless, because they catch political officials at church, in the grocery store, at the barbershops regaling them with how important HSTA is to their family and community.

Legislative Support. The HSTA students, parents and community leaders have worked hard to keep their legislators aware of how important HSTA is to them and their families. The students visit the legislators annually both locally and at the WV State House to thank them for their support and to display the community problems they address and community service that occurs because of their support. HSTA students have contributed over 225,000 hours of community service to their local communities by participating in projects such as helping to stock local food pantries or interacting with pre-school children to help them understand

Table 2. Long-Term Funding Sources.

\begin{tabular}{ll}
\hline Major National, State and Foundation Support & Amount \\
\hline West Virginia Legislature & $\$ 28,294,785$ \\
National Institutes of Health & $\$ 7,391,815$ \\
Howard Hughes Medical Institute & $\$ 1,709,307$ \\
\hline
\end{tabular}

\section{Health Sciences \& Technology Academy}

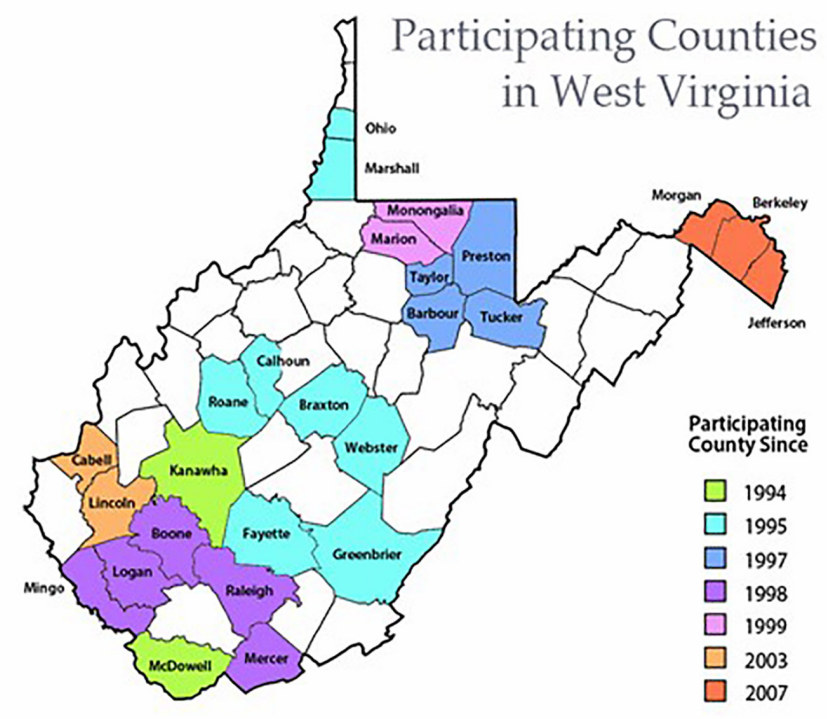

Figure 4. Expansion of HSTA over 26 years.

the importance of physical activity and a healthy diet. The Legislators understand that HSTA is making an indelible imprint on the WV communities it serves, and they are a partner without whom HSTA could not exist. Support has been bipartisan across 23 years.

National Support. The National Institutes of Health Science Education Partnership Award (NIH SEPA) has been key in growing HSTA's expansion into multiple counties in the state. NIH SEPA funding was also critical to improving the science rigor of HSTA student projects from kit-centered activities in the early years to citizen science research with working scientists as partners today. Through a long-term partnership with NIH SEPA, HSTA has demonstrated the potential as a national model of livability, viability, sustainability and scalability.

\section{CHALLENGES AND BARRIERS}

Consistent dependable funding is the greatest challenge to sustainability. Granting agencies often only fund a program for 1 to 5 years with no renewal options. Those granting agencies that do offer consecutive funding frequently require major strategy or content shifts for the new proposal to be competitive. Programs trying to remain funded with this kind of source find it difficult to stay on mission and be purely grant funded. When the state legislature is a source of funding, the elected officials change constantly as does the economic status of the state, making continual education of the legislators time consuming yet critical for survival, especially during budget crises. Add to that, when university leadership is involved with educating the legislators, their 
priorities may not be the same and outreach programming may be the first thing they try to use to reduce their budget requests. This is particularly likely when new leadership arrives to find a budget shortfall, and they have no understanding of the significance of outreach programs in driving their incoming freshmen student body.

The belief that high school students are too young to be trusted to partner in research or even collect data is another challenge. Although HSTA does not suffer anymore from this, dismantling this belief took a decade inside the WVU institution through successful partnerships with faculty. HSTA students have worked with researchers at the University of Pittsburgh (Bardwell et al., 2009; Branch and Chester, 2009; Branch et al., 2011; Branch et al., 2014) and Dartmouth (Siciliano et al., 2018).

Ownership and territorialism can be a challenge as well. This organization runs best when everyone takes ownership, and it is not a dictatorship. The collective wisdom is the strongest. Historically, some leaders have tried to assume authority over who is accepted into HSTA. With community leadership, this was quickly resolved each time. Several times a university CFO assumed authority over the budget or hiring choice and attempted to allocate funds differently than the community had budgeted; however, community leadership was able to resolve this problem quickly.

Change is difficult for many. Creativity can be cramped if a leader is unwilling to explore novel approaches or to test new partnerships. With constant help from multiple sources, HSTA has navigated through all of these pitfalls so far.

Evaluation is a challenge. Conducting an evaluation with a random control trial, or even a reasonable control group is nearly impossible and not ethical when working with students whose futures are dramatically changed by the decision allowing them into HSTA. Tracking participants and non-participants for over two decades is very difficult, time-consuming, and costly. Nevertheless, HSTA has managed to track all but 189 of its nearly 3000 graduates successfully.

HSTA still has untapped potential to generate dollars in revenue for colleges while increasing their student body with underrepresented students. The HSTA waiver is no money changing hands. The costs are simply forgiven by the college. Colleges accepting the waiver are not receiving the dollars they normally would from a student. Historically, HSTA has not focused on standardized test preparation. Yet, HSTA graduates carry earning power for colleges if they qualified for more financial aid. Students with higher SAT scores qualify for more financial aid. Those real dollars from Pell, WV Promise, and merit-based scholarships reduce the impact of the waiver on the institution when colleges use the real dollars to cover costs before they exercise the waiver. HSTA is starting to explore the potential of reducing the impact of the waiver and increasing the income this under- served population can bring to colleges. For the first time in summer 2020, rising 12th grade students received a free opportunity for test preparation under highly mentored conditions in hopes they would get higher scores and qualify for more funds, reducing the need for colleges to absorb the costs of the waiver. HSTA also covers the costs for taking the test two times. The SAT scores for HSTA participants $(\mathrm{N}=36)$ who took the test this summer ranged from 950 to 1025 showing an average point increase of 69 points with a $15 \%, 3 \%$ and $8 \%$ increase in math, reading and total scores, respectively. McKendall, et al. (2019) presents a detailed comparison of academic performance measures, specifically college GPA, ACT and SAT scores between HSTA and non-HSTA students.

\section{CONCLUSION}

HSTA graduates are high performing students who often qualify for federal Pell grants, state scholarships, federal aid, and they bring their own money, often holding a job through college. Despite the waiver, the average HSTA student brings money into the colleges; money that those colleges would not have seen if it were not for HSTA.

The Health Sciences and Technology Academy is a model for West Virginia and the nation that taps into raising the educational attainment of a typically non-college going portion of the population. It engages them in the science of community problem solving for better health over the course of four years of high school and beyond. HSTA identifies high performing students from low socio-economic communities and provides them with a four-year experience that equips them to continue high academic performance and career development beyond high school. The program has built trust within

Table 3. Degrees of Graduated HSTA Students from 1998 to 2020.

\begin{tabular}{llllll}
\hline \multicolumn{3}{c}{ Health Sciences } & \multicolumn{2}{c}{ STEM } & \multicolumn{2}{c}{ Other } \\
\hline Certificate & 30 & Certificate & 2 & Certificate & 3 \\
Associate & 126 & Associate & 10 & Associate & 35 \\
Bachelors & 291 & Bachelors & 92 & Bachelors & 408 \\
Masters & 90 & Masters & 26 & Masters & 132 \\
DDS & 7 & DVM & 4 & PhD & 3 \\
DPT & 12 & PhD & 2 & Law & 13 \\
DO & 7 & & & & \\
MD & 23 & & & & \\
NP & 7 & & & & \\
PA & 11 & & & \\
PharmD & 23 & & & \\
PhD & 12 & & & \\
\hline Sub-Total & 639 & & & \\
Total & 1369 & & & \\
\hline Note: Health Sciences Associates and Certificate degrees include LPN, Nursing, \\
Medical Assistants, RadiologyTechnologist, etc.
\end{tabular}


local communities, the WV legislature, and WV higher education institutions to create the tuition-waiver incentive for sustainability. We know that higher educational attainment correlates with higher earning power and better health (Hahn and Truman, 2015; Tamborini et al., 2015). These students far exceed the educational levels of their parents. They are breaking the generational cycle of poverty (Feinstein et al., 2008). They are going into STEM/health majors (57\%) and going beyond a bachelors degree $29 \%$ of the time and graduating with STEM degrees (Table 3). Furthermore, $84 \%$ stay after graduation to live and work in WV, which suffers from "brain drain" (McElwee, 2019; Milligan, 2019). HSTA's goal is to expand the model to more WV counties as well as to other states such as Alabama, Mississippi, Delaware and Pennsylvania. HSTA is a model for "Brain Gain" ready for replication across WV and across the nation.

\section{AUTHOR INFORMATION Corresponding Author}

Sherron McKendall, PhD. PO Box 9026, 3006 HSN Health Sciences and Technology Academy. Morgantown, WV 26506.smckendall@hsc.wvu.edu

\section{Author Contributions}

The manuscript was written through contributions of all authors. All authors have given approval to the final version of the manuscript.

\section{ACKNOWLEDGMENTS}

The authors would like to acknowledge the strong support and dedication of the HSTA Joint Governing Board and Local Governing Boards throughout the state of WV. In addition, we wish to acknowledge the many wonderful teachers and staff who have dedicated their skills and time to making opportunities for deserving students. We also want to recognize all the legislators over the history of HSTA who have stood strong in bipartisan support through budget crises to maintain the level of funding needed to sustain HSTA for all these years.

\section{ABBREVIATIONS}

CRA: Community Research Associate; HHMI: Howard Hughes Medical Institute; HSTA: Health Sciences and Technology Academy; IES: Institute of Education Sciences; MU: Marshall University; NIH: National Institutes of Health; NSSE: National Survey of Student Engagement; OST: Out of School Time; SEPA: Science Education Partnership Award; STEM: Science, Technology, Engineering, and Math; WVHEPC: West Virginia Higher Education Policy Commission; WVU: West Virginia University

\section{REFERENCES}

Bardwell, G., Morton, C., Chester, A., Pancoska, P., Buch, S., Cecchetti, A., Vecchio, M., PaulsenS., Groark, S., and Branch, R. (2009). Feasibility of adolescents to conduct community based participatory research on obesity and diabetes in rural Appalachia. Clinical Translational Science, 2(5), 350-354.

Baran, E., Canbazoglu Bilici, S., Mesutoglu, C., and Ocak, C. (2019). The impact of an out-of-school stem education program on students' attitudes toward stem and stem careers. School Science and Mathematics, 119(4), 223-235. doi.org/10.1111/ssm.12330

Beer, G., Le Blanc, M., and Miller, M. J. (2008). Summer learning camps: helping students to prepare for college. College Student Journal, 42(3), 930-938.

Bialeschki, M. D. (2007). The three rs for experiential education researchers. Journal of Experiential Education, 29(3), 366-368. doi.org/10.1177/105382590702900307.

Branch, R., and Chester, A. (2009). Community based participatory clinical research in obesity by adolescents: pipeline for researchers of the future. Clinical Translational Science. 2(5): 340-349.

Branch, R., Chester, A., Morton-McSwain, C., Al Ayubi, S., Bhat Schelbert, K., Brimson, P., Buch, S., Cannon, Y., Groark, S., Hanks, S., Nukui, T., Pancoska, P., Parmanto, B., Paulsen, S., and Wahl, E. (2011). A novel approach to adolescent obesity in rural Appalachia of West Virginia: educating adolescents as family health coaches and research investigators, Topics in the Prevention, Treatment and Complications of Type 2 Diabetes, Mark B. Zimering (Ed.). ISBN: 978-953-307-590-7, In Tech. Available: http://www.intechopen.com/articles/show/title/a-novel-approach-to-adolescent-obesity-in-rural-appalachia-of-west-virginia-educating-adolescents-as [Accessed 22-Oct-2018].

Branch, R., Chester, A., Hanks, S., Kuhn, S., McMillion, M., Morton McSwain, C., Paulsen, S., Para, U., Cannon, Y., and Groark S. (2014). Obesity management organized by adolescents in rural Appalachia. Obesity Interventions in Underserved Communities: Evidence and Directions. 205212.

Carver, C. S. (1997). You want to measure coping but your protocol's too long: Consider the Brief COPE. International Journal of Behavioral Medicine, 4, 92-100.

Castleman, B. L., and Page, L. C. (2015). Summer nudging: can personalized text messages and peer mentor outreach increase college going among low-income high school graduates? Journal of Economic Behavior and Organization, 115, 144-160. doi.org/10.1016/j.jebo.2014.12.008.

Chan, W. Y., Kuperminc, G. P., Seitz, S., Wilson, C., and Khatib, N. (2019). School-based group mentoring and academic outcomes in vulnerable high-school students. Youth and Society, 1-18. doi.org/10.1177/0044118x19864834. 
Chester, A., Hanks, S., Kuhn, S., Jones, F., White, T., Harris, M., Hornbeck, B., McKendall, S., McMillion, M., Morton, C., Slusser, M., and Saunders, R. K. (2018). Social media based STEM enrichment curriculum positively impacts rural adolescent health measures. Journal of STEM Outreach, 1(1), 1-12. doi.org/10.15695/jstem/v1i1.17.

Chester, A., and Dooley, E. (2011). West Virginia University's Health Sciences and Technology Academy. Journal of Higher Education Outreach and Engagement, 15(3), 8799.

Chittum, J. R., Jones, B. D., Akalin, S., and Schram Ásta B. (2017). The effects of an afterschool stem program on students' motivation and engagement. International Journal of STEM Education, 4(1), 1-16. doi.org/10.1186/s40594017-0065-4.

College Board Advocacy and Policy Center (2012). The College Completion Agenda 2012 Progress Report. Retrieved from https://secure-media.collegeboard.org/digitalServices/ $\mathrm{pdf} /$ advocacy/policycenter/college-completion-agenda-2012-progress-report.pdf.

Dewey, J. (1938). Experience and education. New York: Collier.

Donham, J. (2014). College ready-what can we learn from firstyear college assignments? An examination of assignments in Iowa colleges and universities. School Library Media Research, 17, 1-21. Retrieved from http://www.ala.org/ aasl/sites/ala.org.aasl/files/content/aaslpubsandjournals/ slr/vol17/SLR_CollegeReady_V17.pdf.

Edmunds, J., Arshavsky, N., Glennie, E., Charles, K., and Rice, O. (2017). The Relationship between project based learning and rigor in STEM-focused high schools. Interdisciplinary Journal of Problem-Based Learning, 11(1). doi. org/10.7771/1541-5015.1618.

Elza, S. (2019). WVU Today: Health Sciences and Technology Academy celebrates 25 years of mentorship and empowerment. Retrieved June 23, 2020, from https://wvutoday. wvu.edu/stories/2019/10/10/health-sciences-and-technology-academy-celebrates-25-years-of-mentorship-and-empowerment.

Fairmont State University. Student Services: Turley Student Services Center. (n.d.). Retrieved August 20, 2020, from https://www.fairmontstate.edu/studentservices/.

Feinstein, L., Duckworth, K., and Sabates, R. (2008). Education and the family: passing success across the generations (Ser. Foundations and futures of education). Routledge.

Fix, G. M., Ritzen, H. T., Pieters, J. M., and Kuiper, W. A. (2019). Effective curricula for at-risk students in vocational education: A study of teachers' practice. Empirical Research in Vocational Education and Training, 11(1). doi:10.1186/ s40461-018-0076-5.

Griffith, C. (2019). HSTA: Building West Virginia's STEM work force. Retrieved May 12, 2020, from https://www. wvnews.com/news/wvnews/hsta-building-west- virginias-stem-work-force/article_5bcca318-0881-57a3-a0bf-cd9cf7ab2824.html.
Hahn, R. A., and Truman, B. I. (2015). Education improves public health and promotes health equity. International Journal of Health Services: Planning, Administration, Evaluation, 45(4), 657-78. doi.org/10.1177/0020731415585986.

Harris, P. A., Taylor, R., Minor, B. L., Elliott, V., Fernandez, M., O’Neal, L. McLeod, L., Delacqua, G., Delacqua, F., Kirby, J., and Duda, S. N. (2019). The REDCap consortium: Building an international community of software platform partners. Journal of Biomedical Informatics, 95, 103208. doi:10.1016/j.jbi.2019.103208.

Health Sciences and Technology Academy. (2019). What is HSTA? http://wv-hsta.org/media/13419/1 what-is-hsta-1-2020. pdf. [Accessed 26-May-2020].

Health Sciences and Technology Academy On-line Surveys. (2015-2020). Student and teacher qualitative responses.

Health Sciences and Technology Academy (HSTA). (n.d.). Retrieved August 20, 2020, from http://www.wv-hsta.org/ alumni-association/

Heuer R., Mason, M., and Lauff, E. (2016, September). Upward Bound and Upward Bound Math-Science Programs Postsecondary Outcomes Report. Retrieved from https:// www2.ed.gov/programs/trioupbound/ub-ubms-outcomes2016 .pdf.

Hurtado, S., Arellano, L., Cuellar, M., and Guillermo-Wann, C. (n.d.). Diverse learning environments survey: Select factors. Retrieved from https://www.heri.ucla.edu/ford/ downloads/Introduction to_DLE_12262011.pptx

Hutson, T., Cooper, S., and Talbot, T. (2011). Describing connections between science content and future careers: implementing Texas curriculum for rural at-risk high school students using purposefully-designed field trips. The Rural Educator, 33. doi.org/10.35608/ruraled.v33i1.421.

Hutton, P. (2014). WV Physician Magazine Volume 5, Issue 2. Retrieved May 21, 2020, from https://issuu.com/wvphysicianmagazine/docs/wvp_vol5_issue2_final/14.

Institute of Education Sciences (IES). (2019). STEM bachelor's degrees as a percentage of total bachelor's degrees conferred by postsecondary institutions, by race/ethnicity: Academic year 2015-16. National Center for Education Statistics. Retrieved: https://nces.ed.gov/programs/raceindicators/indicator_reg.asp.

Kang, S. H. K. (2016). Spaced repetition promotes efficient and effective learning: policy implications for instruction. Policy Insights from the Behavioral and Brain Sciences, 3(1), 12-19. doi.org/10.1177/2372732215624708.

Kitchen, J. A., Sonnert, G., and Sadler, P. M. (2018). The impact of college- and university-run high school summer programs on students' end of high school stem career aspirations. Science Education, 102(3), 529-547. doi.org/10.1002/ sce. 21332 .

Kristjansson, A., and Mann, M.J. (2018). Evaluation of HSTA. Final Report. http://wv-hsta.org/media/13322/aec-final-report-january-2018-final.pdf. 
Krishnamurthi, A., Ballard, M., and Noam, G. G. (2014). Afterschool Alliance, and Program in Education, Afterschool and Resiliency (PEAR). Examining the impact of afterschool stem programs. Distributed by ERIC Clearinghouse. https://eric.ed.gov/?id=ED546628.

Lescak, E. A., O’Neill, K. M., Collu, G. M., and Das, S. (2019). Ten simple rules for providing a meaningful research experience to high school students. Plos Computational Biology, 15(4), 1-7. doi.org/10.1371/journal.pcbi.1006920.

Marshall University (2017, June 02). Come to Class! Retrieved August 20, 2020, from https://www.marshall.edu/hpp/ about-the-program/.

Martinez, M., and Klopott, S. (2005). The Link between High School Reform and College Access and Success for Low-Income and Minority Youth. Retrieved May 05, 2020, from https://www.aypf.org/wpcontent/uploads/2014/07/ HSReformCollegeAccessandSuccess.pdf.

McElwee, C. (2019, August 18). Charles McElwee: What the brain drain is costing us. Retrieved June 20, 2020, from https:// www.wvgazettemail.com/opinion/op_ed_commentaries/ charles-mcelwee-what-the-brain-drain-is-costing-us/article_c4e10f12-5d2f-5657-a89f-5c0d058ceeaf.html.

McKendall, S. B., Simoyi, P., Chester, A. L., and Rye, J. A. (2000). The Health Sciences and Technology Academy. Academic Medicine, 75(Supplement). doi:10.1097/00001888200010001-00039.

McKendall, S. B., Kasten, K., Hanks, S., and Chester, A. (2014). The Health Sciences and Technology Academy: An educational pipeline to address health care disparities in West Virginia. Academic Medicine, 89(1), 37-42. doi. org/10.1097/ACM.0000000000000047.

McKendall, S. B., McKendall, A., and Chester, A. (2019). A comparison of academic performance measures of HSTA participants with non-HSTA participants: Is it possible to narrow the African American-White achievement gap? Journal of STEM Outreach, 2(1). doi:10.15695/jstem/ v2i1.20.

Mercer, J. (1992). 10 states offer tuition waivers to at-risk students in effort to keep them in school and out of trouble. The Chronicle of Higher Education. Retrieved May 7, 2020, from https://www-chronicle-com.www.libproxy.wvu.edu/ article/10-States-Offer-Tuition/72571.

Midgley, C., Maehr, M. L., Hruda, L. Z., Anderman, E., Anderman, L., Freeman, K. E., Gheen, M., Kaplan, A., Kuma, R., Middleton, M. J., Nelson, J., Roeser, R., and Urdan, T. (2000). Manual for the patterns of adaptive learning scales. University of Michigan, Ann Arbor, MI. Retrieved August 17, 2020, from http://www.umich.edu/ pals/PALS $\% 20$ 2000_V13Word97.pdf.

Milligan, S. (2019, June). As highly educated residents move away, states try to minimize 'brain drain' effects. Retrieved June 20, 2020, from https://www.usnews.com/news/best-states/ articles/2019-06-12/how-brain-drain-makes-social-segregation-and-political-division-worse.
Mohr-Schroeder, M. J., Jackson, C., Miller, M., Walcott, B., Little, D. L., Speler, L., Schooler, W., and Schroeder, D. C. (2014). Developing middle school students' interests in stem via summer learning experiences: see blue stem camp. School Science and Mathematics, 114(6), 291-301.

National Survey of Student Engagement (NSSE). (2007). Experiences that matter: Enhancing student learning and success. Bloomington, IN: Center for Postsecondary Research.

Noguera, P., Darling-Hammond, L., and Friedlaender, D. (2015). Equal Opportunity for Deeper Learning. Deeper Learning Research Series. Place of publication not identified: Distributed by ERIC Clearinghouse.

Patel, S. I., Rodríguez, P., and Gonzales, R. J. (2015). The implementation of an innovative high school mentoring program designed to enhance diversity and provide a pathway for future careers in healthcare related fields. Journal of Racial and Ethnic Health Disparities, 2(3), 395-402. doi. org/10.1007/s40615-015-0086-y.

Pendergast, D., Allen, J., McGregor, G., and Ronksley-Pavia, M. (2018). Engaging marginalized, "at-risk" middle-level students: A focus on the importance of a sense of belonging at school. Education Sciences, 8(138), 1-19. doi:10.3390/ educsci8030138.

Podolak, K. R., and Walters, M. J. (2016). High school student physics research experience yields positive results. Physics Education, 51(2), 1-5.

Rendón, L. I. (2000). Academics at heart. About Campus, 5(3), 3-5.

Rendón, L. I. (2006, October). Reconceptualizing Success for Underserved Students in Higher Education. Retrieved May 05, 2020, from https://nces.ed.gov/npec/pdf/resp_Rendon. pdf

Reynolds, J. H., and Glaser, R. (1964). Effects of repetition and spaced review upon retention of a complex learning task. Journal of Educational Psychology, 55(5), 297-308. doi. org/10.1037/h0040734.

Rivers, R., Norris, K. C., Hui, G., Halpern-Felsher, B., DodgeFrancis, C., Guerrero, L. R., The NIDDK high school shortterm research experience for underrepresented persons. Ethnicity and Disease, 30(1), 5-14. doi.org/10.18865/ ed.30.1.5

Rutledge, M. L. (2005). Making the nature of science relevant: Effectiveness of an activity that stresses critical thinking skills. The American Biology Teacher, 67(6), 329-333. doi.org/10.2307/4451857.

Rye, J. A., and Chester, A. L. (1999). WVU-community partnership that provides science and math enrichment for underrepresented high school students. Academic Medicine, 74(4), 352-5. doi:10.1097/00001888-199904000-00022.

Sahin, A. (2013). STEM clubs and science fair competitions: effects on post-secondary matriculation. Journal of Stem Education: Innovations and Research, 14(1), 5-11. 
Siciliano, P., Hornbeck, B., Hanks, S., Kuhn, S., Zbehlik, A., and Chester, A. (2018). Taking a look at the Heath Sciences and Technology Academy (HSTA): Student-research partnership increases survey size, hands-on STEM earning, and research-community connections. Journal of STEM Outreach, 1(1). doi:10.15695/jstem/v1i1.7.

Smith-Branch, F., McKendall, S. B., Chester, A., Hornbeck, B., and McKendall, A. (2018). Demonstrating the efficacy of the Health Sciences and Technology Academy: using archival standardized test scores to analyze an OST college-preparatolry program for underserved youth. Journal of STEM Outreach, 1(1). 1-11. doi.org/10.15695/jstem/ v1il.19.

Stevanovic, K. (2017). How participating in a healthy eating project influenced a targeted group of at-risk students and their engagement in schooling. Journal of the Home Economics Institute of Australia, 24(1), 21-34.

Strayhorn, T. L. (2019). Sense of belonging and student success at historically black colleges and universities. In R.C. Black, R.L. Ford, T.G. Jackson, C.B.W. Prince, and K.D. Rome (Eds.). Advances in Higher Education and Professional Development Examining Student Retention and Engagement Strategies at Historically Black Colleges and Universities, (pp. 32-52). IGI Global. doi:10.4018/978-1-52257021-9.ch003.

Swan, A. K., Inkelas, K. K., Jones, J. N., Pretlow, J., and Keller, T. F. (2018). The role of high school research experiences in shaping students' research self-efficacy and preparation for undergraduate research participation. Journal of the First-Year Experience and Students in Transition, 30(1), $103-120$.

Tamborini, C. R., Kim, C., and Sakamoto, A. (2015). Education and lifetime earnings in the United States. Demography, 52(4), 1383-1407. doi.org/10.1007/s13524-015-0407-0.

Tai, R. H., Liu, Q. C., Maltese, A. V., and Fan, X. (2006). Planning early for careers in science. Science. 312(5777), $1143-1144$.

Tierney, W. G., and Hagedorn, L. S. (2002). Increasing access to college: Extending possibilities for all students (Ser. Suny series, frontiers in education). State University of New York Press.

Tierney, W. G., and Garcia, L. D. (2014). Pullias Center for Higher Education, and University of Southern California. Getting In: Increasing Access to College via Mentoring. Retrieved from https://eric.ed.gov/?id=ED559562.

Tompkins, N.O., Rye, J., Zizzi, S., and Vitullo, E. (2005, November). Engaging rural youth in physical activity promotion research in an after-school setting. Retrieved May 07, 2020, from https://www.ncbi.nlm.nih.gov/pmc/articles/ PMC1459460/.

U.S. Census Bureau QuickFacts: United States. (2018, July). Race and Hispanic Origin. Retrieved from https://www.census. gov/quickfacts/fact/table/US/PST045218.
U.S. Bureau of Labor Statistics. (2017). College enrollment rates of high school graduates in October of the year they graduated from high school, 1993-2016. Retrieved from https://www.bls.gov/opub/ted/2017/69-point-7-percentof-2016-high-school-graduates-enrolled-in-college-in-october-2016.htm.

U.S. Department of Education, National Center for Education Statistics, Higher Education General Information Survey (HEGIS), "Degrees and Other Formal Awards Conferred" surveys, 1970-71 through 1985-86; Integrated Postsecondary Education Data System (IPEDS), "Completions Survey" (IPEDS-C:91-99); and IPEDS Fall 2000 through Fall 2017, Completions component.

West Virginia Higher Education Policy Commission and West Virginia Community and Technical College System (WVHEPC). (2016). West Virginia Higher Education Report Card 2016: West Virginia Higher Education Policy Commission West Virginia Community and Technical College System. Available: http://www.wvhepc.edu/ wp-content/uploads/2017/01/Report-Card.pdf. [Accessed 2-Jan-2019].

West Virginia Higher Education Policy Commission and West Virginia Community and Technical College System (WVHEPC). (2016). West Virginia Higher Education Report Card 2018: West Virginia Higher Education Policy Commission West Virginia Community and Technical College System. Available: https://files.eric.ed.gov/fulltext/ED595737.pdf. [Accessed 2-Jan-2019].

West Virginia University. (n.d.). Student Success: Home. Retrieved August 19, 2020, from https://studentsuccess.wvu.edu/.

Wilson G. S., Pritchard M. E., and Revalee B. (2005). Individual differences in adolescent health symptoms: The effects of gender and coping. Journal of Adolescence, 28(3):369379. doi.org/10.1016/j.adolescence.2004.08.004.

Wilson, D., Kauffman, R., and Purdy, M. (2011). A program for at-risk high school students informed by evolutionary science. Retrieved May 05, 2020, from https://www.ncbi. nlm.nih.gov/pmc/articles/PMC3218050/.

Woodlief, B. Thomas, C., and Orozco, G. (2003). California's gold: Claiming the promise of diversity in our community colleges. Oakland, CA: California Tomorrow.

Wrensford, G. E., Stewart, K. A., and Hurley, M. M. (2019). A health professions pipeline for underrepresented students: middle and high school initiatives. Journal of Racial and Ethnic Health Disparities, 6(1), 207-213. doi.org/10.1007/ s40615-018-0515-9.

Zeldin, S., Gauley, J. S., Barringer, A., and Chapa, B. (2018). How high schools become empowering communities: a mixed-method explanatory inquiry into youth-adult partnership and school engagement. American Journal of Community Psychology, 61(3-4), 358-371. doi.org/10.1002/ ajcp. 12231 . 
Ziegler, B. (n.d.). These U.S. States Have the Best Healthcare. Retrieved May 25, 2020, from https://www.usnews. com/news/best-states/rankings/health-care\#: :text=Hawaii $\% 20$ is $\% 20$ the $\% 20$ top $\% 20$ state, state $\% 20$ for $\% 20$ health $\% 20$ care $\% 20$ below.

Zimet, G. D., Dahlem, N. W., Zimet, S. G., and Farley, G. K. (1988). The multidimensional scale of perceived social support. Journal of Personality Assessment, 52(1), 30-41. doi.org/10.1207/s15327752jpa5201_2.

Zizzi, S., Rye, J., Vitullo, E., and O'Hara-Tomkins, N. (2009). Empowering youth through research: adolescents' perceptions of physical activity interventions in Appalachian communities. Journal of Rural and Community Development. 4(1), 1-14. 